\title{
A DIGITÁLIS ADÓK KÉRDÉSE, KÜLÖNÖS TEKINTETTEL A CSEH SZABÁLYOZÁSRA
}

\section{The Question of Digital Taxes with Special Regard to the Czech Regulation}

\section{Wágner Tamás Zoltán ${ }^{1}$}

\begin{abstract}
Absztrakt: A digitális cégek megadóztatása új kihívást jelent a világ valamennyi országa számára, mivel ezek a cégek a szolgáltatásaikat konkrét fizikai jelenlét nélkül nyújthatják az adott országban. Ezt pedig a jelenlegi adórendszerek nem tudják kezelni, mivel az elmúlt évtizedekben fokozatosan elavulttá váltak. Mindezt súlyosbítja az a tény, hogy ezek a cégek is előszeretettel alkalmaznak adóelkerülési stratégiákat, amelyek dollármilliárdokkal kurtítják meg a költségvetéseket. Éppen ezért az elmúlt néhány évben felerősödtek nemzetközi és uniós szinten azok a törekvések, amelyek átfogó társasági adóreformot kívánnak végrehajtani. E tekintetben az OECD és az Európai Unió élen jár: utóbbi 2018 márciusában egy hosszútávú, valamint egy rövidtávú javaslatot is letett az asztalra. Azonban néhány tagállam ellenállása miatt végül nem született ezekből konkrét irányelvek. Ennek ellenére a digitális adó kérdése nem került le a napirendről: a tagállamok folyamatosan hangsúlyozzák egy átfogó megoldás szükségességét nemzetközi szinten. A tárgyalások jelenleg is tartanak, de eközben egyes tagállamok saját digitális adó javaslatokat dolgoztak ki. Jelen tanulmányban a jogi háttér bemutatása után a cseh javaslatot vesszük górcső alá, majd megvizsgáljuk, hogy milyen kritikák merültek fel a digitális adókkal általánosan és specifikusan.
\end{abstract}

\footnotetext{
1 Wágner Tamás Zoltán a Pázmány Péter Katolikus Egyetem Jog- és Államtudomány Doktori Iskolájának doktorandusz hallgatója, valamint a Kisebbségi Jogvédő Intézet jogásza. Kutatási területei többek között a multinacionális vállalatok adóelkerülési gyakorlatai, valamint az uniós jog és kisebbségvédelem kapcsolódási pontjai. E-mail címe: wagnertomi@,freemail.hu.
}

A szerző további munkásságát lásd a Magyar Tudományos Művek Tára oldalán: https: $/ / \mathrm{m} 2 . \mathrm{mtmt}$. hu $/$ gui2 $/$ ?type $=$ authors\&mode $=$ browse\&sel $=10067284$ 
Kulcsszavak: fizikai jelenlét, adóterhelés, digitalizáció, unilaterális lépés, amerikai válaszintézkedés

\begin{abstract}
The taxation of digital companies poses a new challenge to the countries in the world because these companies provide service without concrete physical presence in the given country. This situation cannot be handled by the current tax systems since they became obsolete in the last decades. All these are aggravated by the fact that these companies also use tax avoidance strategies which curtail state budgets by billions of dollars. Consequently, those efforts intensified on European and international levels in the last years which aim at introducing comprehensive corporate tax reform. In this respect, the European Union and the OECD have a leading role: the former put forward a long-term and an interim proposal in March 2018. But the resistance of several member states prevented the adoption of the respective directives. Despite this failure, the question of digital taxes is still on the agenda: the member states continuously emphasise the necessity of a comprehensive solution on international level. The negotiations concerned are still pending, but in the meantime certain member states elaborated their own versions of digital taxes. In the following study, after the presentation of the legal background, we will analyse the Czech proposal. Then we will examine the general and specific criticism regarding digital taxes.
\end{abstract}

Keywords: physical presence, tax burden, digitalisation, unilateral step, American countermeasure

\title{
BEVEZETÉS
}

Napjainkban komoly kihívást jelent az egyes országok költségvetésére az időközben komoly befolyásra és hatalomra szert tevő multinacionális vállalatok által folytatott különböző adóelkerülési gyakorlatok. Ennek hátterében elsődlegesen az áll, hogy az érintett adórendszerek nem tudják tartani a lépést a globalizáció diktálta változásokkal, és fokozatosan elavulttá válnak. Például a legtöbb ország továbbra is fizikai jelenléthez köti az adózást annak ellenére, hogy a digitális cégek határon átnyúló szolgáltatásai esetében ez - noha az értékteremtés megvalósul - nem teljesül. ${ }^{2}$

\footnotetext{
${ }^{2}$ ERDŐs, 2019. 243.o.
} 
Mindez lehetővé teszi, hogy a multinacionális vállalatok könnyűszerrel dollármilliárdokat csoportosítsanak át az úgynevezett adóparadicsomokba. Ezzel kapcsolatban a nemzetközi szakirodalomban eltérô számok láttak napvilágot, azonban az közös bennük, hogy óriási összegekről van szó. Az Egyesült Államok (a továbbiakban: USA) esetében például az elmaradt adóbevételek ötöde köszönhető ennek, amely évente 100 milliárd dollárt tesz ki. Az Európai Bizottság adatai alapján pedig az Európai Uniót összességében véve 1000 milliárddal károsították meg a multinacionális vállalatok adóelkerülési trükkjei és az adó meg nem fizetése. ${ }^{3}$ A Tax Justice Network számításai szerint világszinten 21-32 ezer milliárd dollárnyi összeget „parkoltatnak” a multinacionális vállalatok adóparadicsomokban, az adóelkerülésből fakadó veszteség pedig eléri az évi 156 milliárd dollárt, ami elegendő lenne a globális méretű szegénység felszámolásához is. ${ }^{4}$

A fentiek fényében nem meglepő, hogy különösen az elmúlt években felerősödtek azok a törekvések, amelyek ezeket a káros, az államok költségvetését fenyegető gyakorlatokat fel kívánják számolni. ${ }^{5} \mathrm{E}$ tekintetben érdemes kiemelnünk az OECD szerepét, mely a nemrég elfogadott BEPSakciótervvel az egyes társasági adórendszerek védelme érdekében minimum standardokat fektetett le nemzetközi színtéren. ${ }^{6}$ Továbbá a globális minimum vállalati adócsomag javaslatával azt célozza, hogy a multinacionális vállalatok akkor is fizessenek adót abban az országban, ahol múködnek, ha egyébként máshol - jellemzően adóparadicsomokban alacsony adókulccsal adóznak. ${ }^{7} \mathrm{E}$ téren az Európai Unió sem kíván lemaradni, amit jól mutat, hogy 2010 után számos javaslat, intézkedés született az adóelkerüléssel szemben. A teljesség igénye nélkül ide sorolható

\footnotetext{
${ }^{3}$ VARGHA, 2017. 195.o.

${ }^{4}$ RAWLINGS, 2017. 653-674.o.

${ }^{5}$ A fellépés azért is indokolt, mivel a multinacionális vállalatok adóelkerülési gyakorlatai a fejlődő országokat sokkal súlyosabban érintik, mint a fejletteket, valamint hozzájárulnak a társadalmi egyenlőtlenségek növeléséhez. Ennek hátterében az áll, hogy a fejlődő országok fokozottan ki vannak téve a globalizáció következményeinek: a befektetôk mindig a kedvezőbb adózási lehetőségeket keresik és a tőke szabad mozgása előtti akadályok megszűnésével ezt nagyon könnyen meg is tudják valósítani. E téren pedig ezek az országok rosszul állnak: úgy kívánják elfedni a politikai-társadalmi bizonytalanságokat, hogy jelentős kedvezményeket biztosítanak a multinacionális vállalatoknak. Mindez viszont azzal jár, hogy a kieső bevételek máshonnan, elsősorban az átlagos adófizetőktől kell beszedniük. Erről részletesen lásd: WÁGNER, 2019. 189-190.o.
}

${ }^{6}$ Action Plan On Base Erosion And Profit Shifting, 2013.

7 PORTFOLIO, 2019. 
az Európai Bizottság közös konszolidált társasági adóalapjavaslata (CCTB) ${ }^{8}$, a 2016-ban elfogadott ATAP-csomag ${ }^{9}$ vagy a Testületnek a multinacionális vállalatoknak nyújtott adókedvezmények elleni „hadjárata”, amelynek keretében már számos nagyvállalat elbukott (gondoljunk csak az Apple esetére, amelytôl 13 milliárd euró visszafizetését rendelte a Bizottság. ${ }^{10}$ Utóbbi akkor is figyelemreméltó, ha időközben az uniós bíróságok egyes határozatokat megsemmisítettek. Ugyanis rávilágít arra, hogy az Európai Unióban több olyan tagállam is van (elsősorban Luxemburg, Hollandia, Belgium és Írország), amelyek adóparadicsomszerűen működnek. Ez viszont könnyen azt eredményezheti, hogy ezen tagállamok útját állják a közös fellépésnek, ahogy arra már több alkalommal is sor került az elmúlt években.

Az Európai Bizottság 2018-ban két javaslatot dolgozott ki az Európai Unióban jelentős tevékenységet folytató digitális cégek megadóztatására:

- ideiglenesen: 3\%-os adó kivetése bizonyos digitális tevékenységek után;

- hosszútávon: a társasági adórendszer megreformálása, melynek keretében a tagállamok adóalapjába integrálnák a „digitális telephely" fogalmát.

Habár a tagállamok döntô többsége támogatta ezeket a javaslatokat, néhány tagállam - mivel az adópolitika területén a jogalkotáshoz az uniós jog egyhangúságot követel meg - azonban sikeresen megakadályozta ezt, többek között arra hivatkozva, hogy uniós szint helyett nemzetközi szinten, az OECD keretében kellene megoldást találni.

Ennek következtében az uniós jogalkotási folyamat megszakadt, ami egyes tagállamokat arra késztetett, hogy önállóan lépjenek fel a multinacionális vállalatok adóelkerülési gyakorlataival szemben. E tekintetben a legnagyobb visszhangot kétségtelenül a francia digitális adó váltotta ki, amelynek következtében néhány hónapig francia-amerikai kereskedelmi háború is fenyegetett. Ezzel szemben viszont sokkal kevesebb szó esett különösen a magyar sajtóban - más országok tervezeteirôl, így például a cseh digitális adóról, amely szintén amerikai célkeresztbe került.

Jelen tanulmányban - tekintettel az esetleges közép-európai vonatkozásokra is - a cseh javaslatra fókuszálva mutatjuk be, hogy az Európai Bizottság - és a tagállamok - milyen új módszerrel kívánnak

\footnotetext{
8 Proposal For a COUnCil directive on a COMmOn Corporate TAX Base, 2016.

9 Anti Tax Avoidance Package, 2016.

10 TAX Rulings, 2013.
} 
fellépni az adóelkerülést folytató multinacionális vállalatokkal szemben. Ennek során elsőként röviden áttekintjük a jogi hátteret, benne a bizottsági javaslatokkal, majd a cseh szabályozást vesszük górcső alá. Végezetül azt vizsgáljuk meg, hogy milyen kritikák fogalmazódtak meg a digitális adóval általánosságban, valamint specifikusan a cseh helyzetre vonatkozóan. Vajon alkalmas eszköznek tekinthetô a digitális adó az adóelkerülés elleni harcban?

\section{JOGI HÁTTÉR}

Az előbbiekben láthattuk, hogy a multinacionális vállalatok adóelkerülési gyakorlatai napjainkban óriási bevételkiesést jelentenek az országok számára, ugyanis az egyes adórendszerek különböző kedvezményein túl ki tudják használni az egyes jogi kiskapukat is. Ez utóbbira jó példát szolgáltatnak a kettôs adóztatást elkerülő egyezmények, ahol az egyes rendelkezések eltérő értelmezései kínálnak jó lehetőségeket a vállalatok számára. E tekintetben érdemes kiemelnünk a McDonald's ügyet, ahol az érintett cég a Luxemburg-USA egyezmény állandó telephelyre vonatkozó eltérő szabályozásra hivatkozva sikeresen mentesült az adófizetési kötelezettség alól mindkét országban. ${ }^{11}$ Mindez azonban csak egy szelete egy óriási problémakörnek. Nem véletlen tehát, hogy az államok és a nemzetközi szervezetek (elsősorban az OECD), valamint az EU az elmúlt időszakban újabb és újabb megoldási javaslatokkal álltak elő, amelyek közül az egyik legfrissebb az Európai Bizottság digitális adóval kapcsolatos tervezetei. Ennek kapcsán viszont fontos hangsúlyoznunk, hogy a bevételkiesés csak okozat, a valódi ok abban keresendő, hogy az elmúlt évtizedek során az egyes államok adórendszerei fokozatosan elavulttá váltak, nem tudják már időben követni a gazdasági változásokat, különösen a digitalizáció jelentette kihívásokat. Éppen ezért - mielőtt a konkrét bizottsági javaslatokra térnénk - célszerű ezt a kérdést is alaposabban megvizsgálnunk. Enélkül ugyanis nem érthetjük meg igazán, hogy a Bizottság és a tagállamok miért ezt az utat választották.

A probléma gyökerei egészen a XX. század közepéig nyúlnak vissza. Ekkor a gazdasági keretek sokkal zártabbak voltak, mint napjainkban és a protekcionista gazdaságpolitikai felfogás volt az uralkodó a világon. Ebben az időszakban a külföldi befektetések száma alacsony volt, az államoknak nem nagyon kellett számolniuk a határon átnyúló gazdasági kapcsolatokkal,

${ }^{11}$ Erről részletesen lásd: WÁGNER, 2019. 194-203.o. 
így adópolitikájuk kialakításakor elegendő volt a hazai viszonyokra fókuszálniuk. A globalizációval azonban fokozatosan megszűntek a tôke szabad áramlása előtti akadályok, a piacok egyre inkább liberalizáltak lettek. Mindez teljesen új helyzetet teremtett: a külföldi befektetők többé már nem voltak „odakötve” egy-egy országhoz, hanem szabadon megválaszthatták a célországot. Ennek következtében viszont az államok - különösen a fejlődők - kiszolgáltatottá váltak, ami ahhoz vezetett, hogy előtérbe került a versenyképesség, vagyis az, hogy ki tud kedvezőbb adózási környezetet biztosítani a befektetők számára. ${ }^{12} \mathrm{Az}$ államok között fokozatosan egy lefelé tartó adóverseny (angol elnevezés: ,race to the bottom') alakult ki, amelyet jól jellemez az a tény, hogy 1980 és 2015 között a társasági adó mértéke 40\%ról 25\%-ra csökkent. ${ }^{13}$ Ezzel párhuzamosan olyan gazdasági átalakulások mentek végbe, amelyek lehetőséget kínáltak a multinacionális vállalatok számára, hogy különböző adóelkerülési stratégiákat fejlesszenek ki, mint például transzferárazás, székhelyáthelyezés vagy egyezményvásárlás. Az utóbbi kapcsán az ún. kettős adóztatást elkerülő egyezmények alkalmazása során felmerülő kiskapukat (angol elnevezés: „loopholes”), kétértelmü rendelkezéseket (angol elnevezés: „mismatches”) használják ki (lásd a McDonald's esetet). A multinacionális vállalatok pozícióját ráadásul tovább erősítette az a tény is, hogy ezekre a változásokra az egyes országok adórendszerei későn vagy egyáltalán nem tudtak reagálni, sőt bizonyos esetekben maguk is hozzájárultak az adóelkerüléshez (adóparadicsomok). Így többek között az egyes adórendszerek továbbra is:

- a leányvállalatokat külön entitásnak tekintik az anyavállalattól, emiatt

- az adóztatásukra is külön-külön kerül sor, ami lehetővé teszi az alacsonyabb adókulcsokat alkalmazó országokba történő profitátcsoportosítást. ${ }^{14}$

Ezeken túlmenően az államoknak manapság a digitális gazdaság jelentette kihívásokkal is szembe kell nézniük. Idetartoznak például az online kereskedelem különböző típusai úgy mint a webáruházak, elektronikus könyvek, filmek, zenék vagy különböző alkalmazások letöltése, online hirdetések, online számlázás, felhőalapú szolgáltatások. ${ }^{15}$ E

\footnotetext{
12 WÁGNER, 2017. 295-296.o.

13 TAX GAMES, 2017. 8.o.

${ }^{14}$ ERDŐs, 2019. 243.o.

15 Az online kereskedelemről bővebben olvashat a Külügyi Múhely 2020/1. számában megjelenő, Szűcs Gáborné: Az online kereskedelem térhódítása és szabályozása c. tanulmányban. Forrás: SzŰCS, 2020.
} 
szolgáltatások közös vonása, hogy azok tárgya jellemzően immateriális javak, a szerződések a szolgáltató és a vásárlók mint távollévők között jönnek létre az interneten keresztül, valamint elektronikus úton zajlik a fizetés. ${ }^{16}$ Habár a digitalizációnak számos pozitív oldala, gondoljunk csak a gyorsaságra, a könnyú elérhetőségre vagy a hatékonyságra ${ }^{17}$, látnunk kell annak árnyoldalait is. Ezt annál is inkább érdemes figyelembe venni, mivel az Európai Bizottság számításai szerint a digitális gazdaság évi 450 milliárd euróval járul hozzá az EU gazdaságához, ami az uniós GDP 4\%-a és ez a szám fokozatosan tovább nő. Ezzel kapcsolatban elegendő arra hivatkoznunk, hogy míg a „hagyományos” gazdaság mindössze évi 0,2\%-kal növekszik, addig a digitális évente $14 \%$-kal. ${ }^{18}$ Ráadásul ezen a területen az államoknak nehézséget jelent az adóztatás is, ami az Európai Bizottság szerint az átlagos adóterhelésben is tükröződik: míg a hagyományos vállalkozásoknál ez az érték 23\%, addig a digitális társaságok esetében ez csak 9,5\%, amit még tovább lehet csökkenteni a különböző adóelkerülési technikákkal. ${ }^{19}$

Utóbbi tekintetében érdemes kiemelnünk, hogy a korábbi, klasszikus üzleti modellben, ha az egyes vállalatok határon átnyúló tevékenységet folytattak, akkor az rendszerint megkövetelte az érintett államban (forrásország) való fizikai jelenlétet (telephely) is. Ez egyúttal azt is jelentette, hogy ott értékteremtő tevékenységet folytattak, ami után teljesítették az adófizetési kötelezettséget. Ennek hátterében az állt, hogy a termelés alapvetően helyhez kötött volt.

A nemzetközi adójogi szabályozás - amelynek alapjai egészen az 1920-as évekre nyúlnak vissza - napjainkban továbbra is ezt az elvet követi: az OECD Modellegyezmény és az arra épülő kettős adóztatás elkerüléséről szóló egyezmények szerint az ún. kapcsoló szabályt - vagyis, hogy a forrásország adóztatási jogkörét gyakorolhassa - az állandó telephely teremti meg, ami fizikai jelenlétre épül. Ilyennek minősül például az iroda, üzletvezetés helye, a műhely, de a függő képviselő intézménye is. ${ }^{20}$ Mindez hármas célt szolgál:

\footnotetext{
16 RÁCZ, 2014. 312-313.o.

17 ERDŐs, 2019. 235.o.

18 COMMISSION STAFF WORKING DOCUMENT, IMPACT ASSESSMENT, 2018.

19 VARGA, 2019. 107-108.o.

${ }^{20} \mathrm{Az}$ a természetes vagy jogi személy, aki a vállalkozás képviselőjeként és annak nevében szerződéseket köt egy másik állam területén.
} 
- adóztatás jogának biztosítását a forrásország infrastruktúrájának és erőforrásainak használatáért;

- belföldi és külföldi tôke azonos adójogi kezelését (tôke importsemlegesség);

- felesleges adminisztrációs teher elkerülése mind az érintett vállalatok, mind az állam oldaláról.

Habár a XX. század eleje óta - különösen az elmúlt néhány évtizedben - óriási mértékű gazdasági átalakulás zajlott le a világon, annak ellenére manapság még mindig ez a koncepció számít egyeduralkodónak. Ebben többek között az is közrejátszhat, hogy eddig mindig sikerült áthidalni az egyes technológiai kihívásokat, mint például a rádió, a televízió vagy a csomagküldő cégek kérdése.

Azonban az elektronikus kereskedelem megjelenése, majd tömegessé válása fokozatosan kikezdte ezt a kapcsoló szabályt. Noha az OECD a Modellegyezmény Kommentárjába iktatta az ezzel kapcsolatos rendelkezéseket, úgy tûnik, hogy több olyan esetkör is van, amikor az elektronikus kereskedelemhez kapcsolódó tevékenység nem tesz eleget az állandó telephely követelményének. Példaként hozhatók fel a különböző weblapokról díj ellenében letölthető elektronikus könyvek ${ }^{21}$. Ennek oka abban keresendő, hogy a digitális cégek tekintetében úgy valósul meg a határon átnyúló szolgáltatás, hogy közben abban az országban nem beszélhetünk tényleges fizikai jelenlétről: vagyis elválik egymástól a nyereség és az adófizetés kötelezettsége. Ez pedig lehetôvé teszi ezen cégeknek, hogy nyereségüket alacsonyabb adókulcsokat alkalmazó országokba csoportosítsák át, bevételkiesést okozva ezzel a forrásországnak. A probléma kapcsán Erdős Éva megjegyzi, hogy ez - noha a tisztességes adózás, valamint a közteherviselés elvét sérti - nem feltétlenül minősül jogellenes tevékenységnek. Többek között ebből fakad, hogy továbbra is kérdéses, hogy milyen tevékenységek után kellene adót fizetni és hogyan adóztathatók meg ezek a vállalatok. ${ }^{22}$ A fellépést pedig csak nehezíti, hogy a szolgáltatás tárgya immateriális jellegú, amely nem illeszthetô be az eddigi koncepcióba. Mindez azt mutatja, hogy olyan új kapcsoló szabályra van szükség, amely választ tudni adni a digitalizációból eredő kihívásokra.

A fentiek fényében nem meglepő, hogy az elmúlt néhány évben felgyorsultak azok a törekvések, melyek azt célozzák, hogy ezt az adózási

\footnotetext{
${ }^{21}$ RÁCZ, 2014. 314-317.o.

22 ERDŐs, 2019. 235-236.o.
} 
joghézagot felszámolják. E tekintetben a két legaktívabb nemzetközi szereplő az OECD, illetve az Európai Unió. Elóbbi az OECD BEPS melyet a bevezetőben is említettünk - keretében többek között azt szorgalmazza, hogy be kellene vezetni a Modellegyezmény módosításával a „jelentôs digitális jelenlét”-et mint új kapcsoló szabályt, amely kiegészítené az eddigi telephely koncepciót. Mindez azt jelentené, hogy a fizikai jelenlétet a gazdasági jelenlét váltaná fel, amely lehetôséget kínálna arra, hogy az országok érvényesíthessék az adóztatáshoz való jogukat. ${ }^{23}$ Az Európai Unió - azon belül is az Európai Bizottság - éppen ezt a gondolatot karolta fel, amikor kidolgozta a digitális cégek megadóztatására vonatkozó javaslatait. Az elkövetkezőkben röviden ezeket fogjuk áttekinteni.

E tekintetben fontos hangsúlyoznunk, hogy az Európai Bizottság célja egy átfogó szabályozás megteremtése volt, ugyanakkor azzal is tisztában volt, hogy - az eltérő érdekek miatt - idő kell ahhoz, hogy a tagállamok e mellé felsorakozzanak. Éppen ezért 2018 márciusában egyszerre két javaslatot (irányelvet) hozott nyilvánosságra a digitális cégek megadóztatásával kapcsolatban. A Testület szerint ugyanis a jelenlegi társasági adójogszabályok nem felelnek meg a globális gazdaság kihívásainak, ahol az egyes cégek már közvetlen fizikai jelenlét nélkül is képesek profitot elérni a digitális szolgáltatások révén. Ennek következtében pedig az értékteremtés és az adófizetés helye elválik. ${ }^{24}$ A javaslatok erre kínálnak megoldást, egészen addig amíg az OECD keretében nem születik meg a világszintű szabályozás, mely a közösségi helyébe lépne. ${ }^{25}$

Ezek közül a hosszútávú javaslat ${ }^{26}$ a jelenlegi társasági adórendszer megreformálását szorgalmazza. Ennek lényege, hogy a jelenlegi szabályozás kiegészülne a ,jelentős digitális jelenlét”, mint adóztatási jogosultságot eredményező kapcsolószabállyal, valamint a "digitális állandó telephely" egységes definícióját a tagállamok közös konszolidált társasági adóalapjába (CCTB) építenék be. Ezzel tulajdonképpen egyszerre valósulna a Bizottság egyik régi terve, valamint válna lehetôvé a digitális tevékenységek közös szabályok alapján való megadóztatása az Európai Unióban.

A konkrét szabályozásra térve ki kell emelnünk, hogy az irányelv elsősorban az Európai Unión belüli határon átnyúló digitális tevékenységek

${ }^{23}$ RÁCZ, 2014. 319-320.o.

${ }^{24}$ FAir TAXation OF THE Digital ECONOMY, 2018.

25 VARGA, 2019. 108-109.o.

26 Proposal FOr a COUNCIL DIRECTIVE LAYING DOWN RULES RELATING TO THE CORPORATE TAXATION OF A SIGNIFICANT DIGITAL PRESENCE, 2018. 
tekintetében kerülne alkalmazásra, még akkor is, ha a tagállamok között hatályban levő kettős adóztatást elkerülő egyezményeket nem módosították ennek megfelelően. Ugyanakkor ezen túlmenően az irányelv hatálya kiterjedne azon nem tagállami honosságú vállalatokra is, amelyek jelentős digitális jelenléttel rendelkeznek egy olyan tagállamban, amelynek nincs kettős adóztatást elkerülő egyezménye az érintett harmadik országgal. Szintén döntő kérdés az érintett tevékenységek körének lehatárolása. Erre az irányelv 3. cikke ad választ, melynek értelmében digitális szolgáltatásnak minősül az a szolgáltatás, amelyet az interneten vagy elektronikus hálózaton keresztül nyújtanak, természetét tekintve automatizált, minimális emberi beavatkozást igényel és információs technológia hiányában lehetetlen biztosítani pl: digitalizált termékek nyújtása (elsősorban szoftverek). Az irányelv a digitális cégek nyereségét kívánja megadóztatni. Ahhoz azonban, hogy az adott vállalat adókötelezettsége megállapítható legyen, teljesülnie kell a jelentôs digitális jelenlétre vonatkozó kritériumok közül legalább egynek, melyek az alábbiak:

- egy adott tagállamban az éves bevétel meghaladja a 7 millió eurót;

- több mint 100 ezer felhasználója van egy adott tagállamban az érintett adóköteles évben;

- az adott cég és az ügyfelek között több mint 3000 digitális szolgáltatásra irányuló üzleti szerződés jött létre az érintett adóköteles évben.

Végezetül az 5. cikk tartalmazza a tagállamok közötti profitallokációval kapcsolatos szabályokat, melyeknek az a céljuk, hogy biztosítsák, hogy a digitális vállalatok valóban az értékteremtés helyén adóznak. Ennek során a felhasználói adatokból származó nyereség, a felhasználók összeköttetését biztosító szolgáltatások, valamint egyéb digitális szolgáltatások piaci értékét veszik figyelembe.

A fentiek alapján jól látszik, hogy ez a javaslat több szempontból is nagy horderejű változásokkal járna, éppen ezért a Bizottság egy ideiglenes javaslatot is megfogalmazott ${ }^{27}$, amely kevésbé ambiciózus, de szintén bevételi forrásokat teremtene a tagállamok számára és elejét venné annak, hogy a tagállamok egyoldalú intézkedéseket vezessenek be a digitális cégek megadóztatására. Ennek érdekében ez is szakít a hagyományos, fizikai jelenléten alapuló adófizetési kötelezettség elvével, amikor célzottan,

27 Proposal FOR A COUNCIL DIRECTIVE ON THE COMMON SYSTEM OF A DIGITAL SERVICES TAX ON REVENUES RESULTING FROM THE PROVISION OF CERTAIN DIGITAL SERVICES, 2018. 
bizonyos digitális szolgáltatások teljesítéséből fakadó bevételek adókötelezettségét írja elő (digitális szolgáltatási adó). A javaslat ezzel alapvetôen az alábbi célkitűzéseket kívánja megvalósítani:

- a belső piac integritásának védelme és megfelelő múködésének biztosítása,

- közkiadások fenntarthatóságának biztosítása, valamint a tagállami adóalapok eróziójának megakadályozása,

- társadalmi igazságosság és egyenlő feltételek biztosítása valamennyi, az Európai Unióban múködő vállalat számára,

- agresszív adótervezés elleni harc elősegítése, valamint a jogi kiskapuk bezárása.

Mindez azt mutatja, hogy az Európai Bizottság nem pusztán a közteherviselésbe kívánja bevonni a digitális cégeket, hanem ezen keresztül további lépéseket akar tenni az adóelkerüléssel szemben is, amely az egész Európai Unió számára komoly kihívást jelent. Nem véletlen tehát, hogy a tervezet a korábban bemutatott hosszútávú javaslattal együtt jól illeszkedik az Európai Bizottságnak a multinacionális vállalatok adóelkerülési stratégiái elleni terveibe: e tekintetben úgy tûnik, hogy az állami támogatások alapján lefolytatott vizsgálatok jelentik az egyedi ügyekben való fellépést, míg a társasági adó reformja, valamint a digitális szolgáltatási adó állandó megoldásnak számítana.

A konkrét szabályozásra visszatérve érdemes kiemelnünk, hogy a tervezet már előzetesen azzal számol, hogy a tagállamok a kettôs adóztatás elkerülése érdekében lehetővé fogják tenni, hogy a társasági adó összegéből le lehessen vonni a digitális szolgáltatási adót abban az esetben, ha az érintett jövedelem mindkét adónem tárgyát képezné. Ennek alapján úgy látszik, hogy az Európai Bizottság is tudatában van annak, hogy egy új, uniós szintủ adó bevezetése - a jelenlegi adórendszerek komplexitása miatt - során a szabályozásnak rugalmasnak kell lennie, elkerülve ezzel azt a helyzetet, hogy az érintett adóalanyoknak túlzottan nagy legyen a terhelése.

Ezen túlmenően, ahogy azt korábban említettük, a Bizottság tervezetei célzottak. Egyrészt, meghatározott szolgáltatások, másrészt ennek nyomán jól körülhatárolható cégek ellen irányulnak. Ez a tény az ideiglenes javaslatra fokozottan is igaz: ugyanis elsősorban azon bevételek megadóztatását célozza, amelyekben a felhasználók döntő szerepet játszanak az értékteremtésben és a hagyományos adórendszerek segítségével szinte lehetetlen bevonni ezeket a közteherviselésbe. Éppen ezért a javaslat az alábbi digitális szolgáltatásokra terjed ki: 
- online hirdetési felületek értékesítéséből származó bevételek,

- digitális közvetítői tevékenységekből származó bevételek, amelyek lehetővé teszik az egyes felhasználók számára, hogy más felhasználókkal interakcióba lépjenek, valamint amely elősegíti a javak és szolgáltatások értékesítését közöttük,

- felhasználók által szolgáltatott információkból kinyert adatok értékesítéséből származó bevételek.

Emellett - a magas küszöbök miatt - csak a legnagyobb, döntően külföldi cégek lennének érintettek, hiszen az adófizetési kötelezettség csak akkor állna be, ha az adóalany világjövedelme az adott pénzügyi évben meghaladja a 750 millió eurót, míg az uniós tagállamokból származó az 50 millió eurót (vállalatcsoportnál az egész csoport tekintetében kell ezeknek a számoknak teljesülniük). Ebben az esetben az adóalany érintett bevételeit 3\%-os adó sújtaná. ${ }^{28}$ Hasonlóan az előző javaslathoz, a digitális szolgáltatási adó is részletes szabályozást tartalmaz többek között az adófizetés helyére, az egyes tagállamok közötti allokációra, a túlfizetésre, valamint az egyes tagállami hatóságok együttmúködésére vonatkozóan.

Habár a tagállamok döntő többsége egyetértett az Európai Bizottság fenti javaslataival és előzetesen 2018 decemberéig tervezték azokat elfogadni, azokból mégsem született uniós szintű jogszabály. Ugyanis az adópolitika területén továbbra is az adószuverenitás elve érvényesül és ahhoz, hogy konkrét jogszabály szülessen, egyhangúságra van szükség az Európai Unió Tanácsában. Ez utóbbi feltétel azonban nem teljesült: néhány tagállam, köztük Dánia, Svédország és Írország ellenezte a kezdeményezést. ${ }^{29}$ Ennek hátterében több ok is állhat. Egyrészt az ellenkező tagállamok közül több is kifejezetten profitál a nagy multinacionális vállalatoknak letelepedéséből. Nem véletlen tehát, hogy jelentős adókedvezményeket biztosítanak nekik, többek között azáltal, hogy hagyják, hogy kihasználják az adórendszerben rejlő jogi kiskapukat. Ennek kapcsán külön is érdemes kiemelnünk Írországot, amely - noha azt vehemensen tagadja adóparadicsomszerűen múködik, amelyet már az Európai Parlament is elismert egy friss határozatában. ${ }^{30} \mathrm{Az}$ ír állapotokat jól jellemzi az Apple ügy is, ahol az érintett vállalat az ír adóhatóság „segítségével” elérte, hogy

\footnotetext{
${ }^{28}$ FAir TAXation OF THE Digital ECONOMY, 2018.

${ }^{29}$ VARGA, 2019. 109.o.

30 Az Európai Parlament 2019. március 26-i állásfoglalása a pénzügyi bűncselekményekről, az adókijátszásról és az adókikerülésről
} 
gyakorlatilag ne kelljen adót fizetnie. Ugyanis két, Írországban bejegyzett leányvállalata nyereségének döntő részét hosszú éveken át a központi iroda nyereségeként tüntette fel, amely - bár csak papíron létezett - az ír jog szerint adómentességet élvezett. Az esetre az Európai Bizottság is felfigyelt: állami támogatásokra vonatkozó szabályok megsértésére hivatkozva vizsgálatot indított, melynek nyomán 13 milliárd euró visszatérítését rendelte el. A helyzetet azonban jól mutatja, hogy Írország nem nyugodott bele a döntésbe és az Európai Törvényszékhez fellebbezett, ahol az ügy még jelenleg is tart. ${ }^{31}$

Másrészt, ahogy arra már a bevezetôben is tettünk utalást, az OECD keretében komoly munka folyik, hogy a digitális cégek jelentette adóztatási kihívásokra hatékony megoldás szülessen globális szinten. E tekintetben pedig számos tagállam is azon az állásponton van, hogy uniós fellépés helyett szélesebb nemzetközi összefogásra van szükség. Ugyanakkor viszont, ha 2020 végéig nem születik megoldás az OECD berkein belül, akkor az uniós tagállamok jelentôs része elkötelezett amellett, hogy uniós szinten vagy egyetértés hiányában akár nemzeti szinten is bevezessék a digitális adót. ${ }^{32}$ Ehhez pedig szorosan kapcsolódik, hogy az USA kritikusan szemléli az Európai Unió, valamint a tagállamok nemzeti szintű törekvéseit, mivel azok döntő részben amerikai vállalatokat céloznának meg. Éppen ezért a jelenlegi Trump-adminisztráció mindent megtesz annak érdekében, hogy az egyes tagállamokat - szankciók kilátásba helyezésével - eltántorítsa az egyoldalú lépések alkalmazásától. ${ }^{33}$ Ráadásul egyes szakértők azt szorgalmazzák, hogy az USA lépjen ki az OECD digitális cégek adóztatásával kapcsolatos munkafolyamatából. Például Adam N. Michel szerint a fizikai jelenléthez kötött adóztatási jogkör alacsonyan tartotta az adókat és élénkítette a világkereskedelmet, ezzel szemben az OECD javaslatai a nemzetközi adórendszert fenyegetik, valamint magasabb adókat jelentenek az amerikai vállalatok számára. ${ }^{34}$ Nem véletlen tehát, hogy az uniós tagállamok inkább abban bíznak, hogy nemzetközi színtéren megállapodás születik, s nem lesz szükség uniós vagy nemzeti digitális adókra.

\footnotetext{
${ }^{31}$ A konkrét ügyről, annak hátteréről, illetve az ír adórendszerről lásd: WÁGNER, 2020.

32 VALERO, 2020.

${ }^{33}$ E tekintetben érdemes kiemelnünk a francia digitális adót (az ún. GAFA adót), amelyre a későbbiek során részletesebben is kitérünk.

${ }^{34}$ N.MiCHEL, 2019. 1.o.
} 
Végezetül több, gazdasági jellegű érvet (például káros hatás a versenyre) is felhoztak az Európai Bizottság javaslataival szemben, ami szintén jelentős befolyást gyakorolhatott a tagállami döntéshozókra. Ezeket részletesen majd a cseh digitális adó kapcsán fogjuk áttekinteni.

Összességében véve jól látszik, hogy napjainkra mind az uniós intézmények, mind a tagállamok döntő többsége előtt nyilvánvalóvá vált, hogy a jelenlegi adózási szabályok nem alkalmasak arra, hogy a digitális cégek is arányosan kivegyék a részüket a közteherviselésből. Szakítani kell tehát a hagyományos felfogással és konkrét fizikai jelenlét hiányában is meg kell teremteni az adóztatás lehetôségét. Ugyanakkor viszont a konkrét megoldás tekintetében továbbra sincs konszenzus a tagállamok között, ami előfeltétele lenne egy uniós szintű jogszabály elfogadásának. Mindazonáltal ez közel sem jelenti azt, hogy a tagállamok ne lennének tudatában a kérdés fontosságának: az elmúlt időszakban többször is hangsúlyozták például a nemzetközi téren történő fellépés szükségességét. Ezt jól mutatja, hogy az Európai Unió nemrég többek között kezdeményezte, hogy a G20 korábban februárra tervezett, majd novemberre halasztott ${ }^{35}$-rijádi soron következő ülésén a 2020-as év prioritása a digitális adóról való megegyezés legyen. ${ }^{36}$ Továbbá a francia pénzügyminiszter aggodalmának adott hangot, ha 2020 végére nem sikerül a világ országainak megegyezniük: ez esetben ugyanis az unilaterális megoldások kerülhetnek elótérbe. ${ }^{37}$

A következő fejezetben éppen ez utóbbi kérdést fogjuk megvizsgálni. E tekintetben pedig látni fogjuk, hogy uniós szintű megoldás hiányában egyes tagállamok - nem várva az OECD globális sztenderdjére egyoldalúan vezettek be digitális adókat. Ezek közül a cseh szabályozást fogjuk részletes elemezni, valamint ennek kapcsán kitérünk a digitális adókkal kapcsolatos általános és specifikus kritikákra is. Vajon tényleg megoldást jelenthet a problémákra a digitális adó?

\section{CSEH DIGITÁLIS ADÓ: KONKRÉT SZABÁLYOZÁS ÉS KRITIKÁK}

Az előző fejezetben részletesen bemutattuk, hogy a digitális cégek megadóztatása napjaink egyik legjelentősebb kihívásává vált. Ennek kapcsán többek között láthattuk, hogy a jelenlegi adórendszerek már nem bizonyulnak hatékonynak e téren: az alapjukat jelentő, konkrét fizikai

\footnotetext{
35 G20.ORG

36 Portfolio, 2020a.

${ }^{37}$ PORTFOLIO, 2020b.
} 
jelenlétre építő kapcsolószabály lényegében véve nem tud mit kezdeni azzal a ténnyel, hogy elvált egymástól a nyereség és az adófizetés kötelezettsége. Mindezt ráadásul tovább súlyosbítja az a tény, hogy a vállalatoknak jellemzően bonyolult a szervezeti struktúrája, valamint jelentős mértékben folytatnak adóoptimalizálási stratégiákat is. ${ }^{38}$

Ezt a helyzetet felismerve mind nemzetközi (OECD), mind uniós szinten (Európai Bizottság) jogalkotási folyamatok kezdődtek meg. Azonban ezeket a törekvéseket nem övezi osztatlan lelkesedés: egyes államok (például Írország) „féltik” a multinacionális vállalatoknak kedvező adórendszerüket, másrészt az USA attól tart, hogy a formálódó tervezetek az amerikai cégek ellen irányulnak, ezért alapvetően kritikus álláspontot képvisel, s esetenként szankciókat helyez kilátásba a cégeit fenyegető egyoldalú állami intézkedésekkel szemben.

Ilyen körülmények közepette került a cseh parlament elé a digitális adó tervezete. Vajon milyen szándék vezérelte a cseh képviselőket? Mi áll annak hátterében, hogy ezt a lépést megtették? Az elkövetkezőkben többek között ezekre a kérdésekre is keressük a válaszokat.

Mindenekelőtt érdemes hangsúlyozni, hogy a cseh digitális adó a nemzetközi, valamint uniós jogalkotási tervezetek szerves folyományának tekinthető és így azokkal együtt kell azt értelmeznünk, illetve értékelnünk. Ennek kapcsán pedig fontos rámutatni arra, hogy habár az Európai Bizottság tervezeteiből az egyhangúság követelménye miatt nem született konkrét jogi aktus, a tagállamok egy részére ennek ellenére - elsősorban a digitális szolgáltatási adó - inspirálólag hatottak és többen is saját digitális adó bevezetésére tettek kísérletet. ${ }^{39}$ Ezek közül a legtöbb figyelmet - ahogy azt korábban említettük - egyértelmúen a francia javaslat kapta, amely már néhány hónappal a közös uniós tervezetek bukása után, 2019 márciusában a francia parlament elé került. A javaslat lényegében véve az uniós digitális szolgáltatási adó elveit követte: az adóalanyisághoz 750 milliós világ és 25 millió eurós franciaországi jövedelem kellett, 3 fó adóköteles tevékenységet ${ }^{40}$ jelölt meg, az adó mértéke - hasonlóan az uniós javaslathoz - 3\% volt. 2019 júliusában a tervezetet a francia parlament január 1-ei visszamenőleges hatállyal elfogadta. A jogszabály csakhamar az USA célkeresztjébe került,

\footnotetext{
38 TESKI-WelthernÉ-MelCHER, 2020. 14.

${ }^{39}$ Erről lásd az alábbi kitekintést: ASEN, 2019.

40 Ezek: digitális platform szolgáltatás a felhasználók interakcióinak elősegítésére a termékek és szolgáltatások kereskedelme érdekében, a digitális platformon történő reklámozás, valamint a reklám pozícionálási célú felhasználói adatok gyújtése és kezelése.
} 
mivel az elsősorban amerikai cégeket sújtott. A vita egy kereskedelmi háború rémképével fenyegetett egy ideig (Donald Trump amerikai elnök több francia termékre is büntetővám bevezetését fontolgatta), végül azonban a felek megállapodtak, hogy 2020 végéig felfüggesztik annak alkalmazását, bízva abban, hogy addig megszületik a megoldás nemzetközi szinten. ${ }^{41}$

Az Európai Bizottság tervezetei mellett a tagállami egyoldalú lépéseknek az is indokául szolgálhatott, hogy az uniós bíróságok az elmúlt időszakban több ügyben is az uniós joggal összeegyeztethetőnek minősítették a vállalkozásokat méret alapján diszkrimináló progresszív adókat. Tekintettel arra, hogy a digitális adónak és a progresszív adóknak több jellemvonása is hasonlóságokat mutat ${ }^{42}$ (például az adó alapja mindkét esetben magas árbevétel), érdemes ezt a kérdést részletesebben is megvizsgálnunk. Ennek kapcsán mindenképp meg kell említenünk az ún. Spanyol tartományok ügyét ${ }^{43}$, ahol Katalónia, Asztúria és Aragónia adót vezetett be a nagy alapterületü kereskedelmi létesítményekre $\left(500 \mathrm{~m}^{2}\right.$, $4000 \mathrm{~m}^{2}$ ), hivatkozva azoknak a környezetre, várostervezésre és a helyi kiskereskedelemre gyakorolt hatására. Az intézkedést a nagy alapterületű kereskedelmi egységek sérelmezték, így az ügy előzetes döntéshozatal formájában az Európai Unió Bírósága elé került, amely többek között kimondta, hogy:

- az adó hatálya alá tartozó, valamint az alól kivett vállalkozások nincsenek hasonló ténybeli és jogi helyzetben,

- a közvetlen adók területén a tagállamoknak autonómiájuk van, ami korlátozott bírósági ellenőrzést tesz lehetővé,

- valamint elfogadható a tartományok azon érvelése, hogy a mérethatáron alapuló megkülönböztetés a kereskedelmi egységek környezetre gyakorolt hatását veszi figyelembe.

Szintén fontos kiemelnünk a lengyel kiskereskedelmi adó esetét ${ }^{44}$ is, ahol az Európai Törvényszék többek között hangsúlyozta, hogy:

- Önmagában véve az adórendszer progresszivitásából nem lehet arra következtetni, hogy amiatt egyes vállalkozások szelektív előnyben részesülnének,

\footnotetext{
41 TeSKI-WelthernÉ-MelCher, 2020. 17.o.

42 BORDÁCS, 2019. 4-13.o.

43 A konkrét ügy részleteiről lásd: STAVICZKY, 2018. 22-23.o.

44 T-836/16. és T-624/17. sz. Lengyelország vs. Európai Bizottság egyesített ügyek
} 
- megismételte, hogy az adó hatálya alá tartozó, valamint az alól kivett vállalkozások nincsenek hasonló ténybeli és jogi helyzetben,

- nem minősül szelektívnek az olyan progresszív adószerkezet, amely bevételalapú és redisztribúciós célokat követ.

Nem véletlen tehát, hogy mindezek fényében Phedon Nicolaides egy tanulmányában egyenesen arról írt, hogy az ilyen döntések kikövezik az utat az olyan adók elótt, amelyeknek kifejezett célja a nagyvállalatok megadóztatása, utalva ezzel arra a tényre, hogy a lengyel ítélet után nem sokkal megszületett a francia digitális adó. ${ }^{45}$

Mindezek tükrében dönthetett arról a cseh kormány 2019. november 18-án ${ }^{46}$, hogy egy digitális adóról szóló tervezetet nyújt be a parlamentnek. A lépés ennek ellenére mindenképp merésznek minősíthető, hiszen ekkor már javában zajlott az amerikai-francia vita és várható volt, hogy az USA erre a kezdeményezésre is hasonlóan reagál majd. Noha a magyar sajtóban keveset foglalkoztak vele, érdemes alaposabban is megvizsgálnunk, mivel több olyan eleme is van, amely kiemeli a többi, hasonló javaslat közül, ráadásul középeurópai adaptációról van szó: a mindenkori magyar jogalkotó számára is hasznos tapasztalatokkal szolgálhat.

Már az elején fontos kiemelnünk, hogy a jogszabálytervezet magyarázata leszögezi, hogy az egyoldalú lépés oka, hogy uniós szinten elakadtak a digitális cégek megadóztatására vonatkozó tervezetek. Azonban az egyoldalú lépés közel sem jelenti azt, hogy Csehország ne támogatná az uniós vagy nemzetközi javaslatokat, sőt éppen ellenkezőleg: ezzel kíván nyomást gyakorolni a nemzetközi intézményekre, hogy megoldást találjanak.

A konkrét szabályozásra ${ }^{47}$ térve megállapíthatjuk, hogy az alapvetően az Európai Bizottság ideiglenes, digitális szolgáltatási adójára épül és az érintett vállalkozások bevételeit adóztatja meg. E tekintetben az adóalanyiságot egy kettős feltétel határozza meg: egyrészt az érintett vállalkozás világjövedelmének el kell érnie a 750 millió eurót, másrészt a hazai bevételeknek meg kell haladniuk a 100 millió cseh koronát (azonban, ha a csehországi digitális szolgáltatásokból származó bevételek nem érik az európai bevételek 10\%-át, akkor nincs adófizetési kötelezettség). Amennyiben az adott vállalat egy vállalatcsoport része, akkor a vállalatcsoport konszolidált bevétele az irányadó. Ezzel szemben nem

\footnotetext{
45 NiCOLAides, 2019.

${ }^{46}$ FUCIK, 2019.

${ }^{47}$ KPMG, 2019.
} 
keletkezik adófizetési kötelezettség a vállalatcsoporton belül nyújtott digitális szolgáltatás után.

A javaslat értelmében az alábbi tevékenységek minősülnének adókötelesnek:

- multilaterális digitális platform használata (küszöbérték 200 ezer felhasználó);

- célzott hirdetés digitális platformon (küszöbérték 5 millió cseh koronás bevétel);

- digitális szolgáltatások felhasználóitól gyűjtött adatok értékesítése (küszöbérték 5 millió cseh koronás bevétel).

Az adó mértéke 7\%, amely az egyik legmagasabb lenne Európában, lényegesen meghaladva a bizottsági tervezetben szereplő 3\%-ot. ${ }^{48} \mathrm{~A}$ javaslat szerint az adó 2020 közepén lépne hatályba és egészen 2024-ig alkalmaznák, attól függően, hogy az OECD keretében mikor születik nemzetközi szinten megoldás.

A korábban említett francia-amerikai vita ellenére a cseh kormány nem számolt amerikai válaszlépéssel, azonban sokan tartottak ettől a lehetőségtől. A cseh ellenzéki pártok közül például többen is úgy vélték, hogy Csehországra is lecsap Trump haragja. E tekintetben érdemes idéznünk Ján Skopečeket, aki a Polgári Demokratikus Párt képviselőjeként úgy fogalmazott, hogy ,illúzió azt gondolni, hogy a pénzügyminisztérium által bevezetni tervezett digitális adót szó nélkül hagyná az Egyesült Államok ${ }^{49}$ ". Egy cseh kommentár ${ }^{50}$ szerint pedig Donald Trump amerikai elnöknek számtalan eszköze van arra, hogy fellépjen a tervezett cseh szabályozás ellen. Ennek kapcsán a cikk emlékeztett arra, hogy korábban a franciák is nagyon elszántak voltak - a föként amerikai - multinacionális cégek megadóztatását illetően, de a kereskedelmi háborútól tartva végül belementek abba, hogy az év végéig felfüggesztik az adó alkalmazását. A lehetséges eszközök tekintetében a szerző kiemeli, hogy az amerikai elnök elődeivel szemben előszeretettel alkalmazza azt a stratégiát, hogy ha nem tud kedvező megegyezést elérni, akkor az adott országgal szemben kereskedelmi és pénzügyi szankciókat vet be, amelyek súlyos gazdasági következményekkel járhatnak az érintett országra nézve. Ugyanis a szankciók extraterritoriálisak, vagyis nemcsak amerikai cégeknek tiltják meg a kereskedést, hanem harmadik országoknak is, beleértve az USA

\footnotetext{
48 ASEN, 2019.

${ }^{49}$ KISS, 2020.

${ }^{50}$ ENGNEWS24H, 2020.
} 
szövetségeseit is. Ez leginkább az ún. dollárfegyverben (angol elnevezés: „dollar weapon”) ölt testet, amire a közelmúltból a legjobb példa Irán, ahol - a választás elé állítással - sikerült rávennie a nyugati cégeket az iráni piacról való kivonulásra. Habár valószínúleg Csehországnak nem kellene ilyen intézkedésekkel szembenéznie, viszont hasonlóan a franciákhoz, neki is fel kellene függesztenie az adó alkalmazását, ha el akarja kerülni a cseh termékeket sújtó büntetôvámokat.

A fenti félelmek megalapozottságát jól mutatja, hogy egy 2019. decemberi kommentárjában az amerikai nagykövet a várható válaszintézkedésekre figyelmeztette Csehországot, ha a tervezetből jogszabály lesz. Ezt követően pedig Eda Findlay, a prágai nagykövetség szóvivője megismételte, hogy Csehország megfelelő válaszintézkedésekre számíthat, ha ténylegesen is bevezeti az adót. Továbbá utalt Steven Mnuchin amerikai pénzügyminiszternek a davosi világgazdasági fórumon elhangzott nyilatkozatára is, amely szintén ugyanezt ecsetelte. ${ }^{51}$

Az ügyben a Csehországi Amerikai Kereskedelmi Kamara is megszólalt ${ }^{52}$, amely az előbbiektől eltérően - a politikai üzengetést kerülve döntően gazdasági-jogi alapokon bírálta a tervezett digitális adót. Közleményükben arra hívták fel a figyelmet, hogy egy adóval nem szabad veszélyeztetni a versenyképes üzleti környezetet, mivel nemcsak az érintett cégekre hathat ki negatívan, hanem az egész ország gazdasági fejlődésére is. Éppen ezért kerülni kell az olyan intézkedéseket, amelyek büntető jellegủek. A tervezett adójavaslat ráadásul több gazdasági kárt fog okozni a cseh gazdaság számára, mint amennyi adóbevételt generálna, valamint alapvető adópolitikai kérdéseket is felvet. Az előbbi kapcsán hangsúlyozzák, hogy a közvetlen gazdasági károkat a cseh cégek fogják elszenvedni, mivel azoknak továbbra is a nagy nemzetközi platformokat kell használniuk, ha el akarnak jutni a célközönségükhöz. Ugyanakkor a közvetett gazdasági károk ennél sokkal súlyosabbak lennének:

- a digitális cégek elfordulhatnak - hivatkozva a kedvezőtlen üzleti környezetre - az országtól, melynek következtében a kutatásaikat máshol folytatnák le (ez különösen a mesterséges intelligenciát érintené);

- ami végül oda vezetne, hogy Csehország, mint befektetési célpont kerülne veszélybe (a kiszámíthatatlan üzleti környezet miatt);

\footnotetext{
${ }^{51}$ Portfolio, 2020c.

52 Amcham Cz Position on Government Digital Tax Proposal, 2019.
} 
- továbbá számolni kellene az amerikai kormány büntető intézkedéseivel is, amely kereskedelmi háborúval fenyegetne és végső soron késleltetné egy átfogó nemzetközi megoldás megszületését.

Emellett adópolitikai szempontból is kritizálták a javaslatot, rámutatva többek között arra, hogy az a nyereség helyett a bevételt adóztatja meg. Ráadásul az adót meghatározott cégekre szabták, elsősorban külföldiekre, ami ellentmond a belső piac szellemiségének. Ezen felül rámutatnak arra, hogy az egyoldalúan kivetett - az adatokat gyưjtő cégek versenyelőnyét kompenzáló - adó helyett más országokkal kellene együttműködni, hogy közös megoldás születhessen a digitális gazdaság megadóztatására.

Végezetül megjegyzik, hogy a javaslat a fentieken túl alkotmányellenes, mivel kettős adóztatással fenyegeti az érintett cégeket, valamint a bilaterális beruházási szerződéseket is sértheti. Éppen ezért azt tanácsolják a cseh kormánynak, hogy az egyoldalú lépés helyett segítse elő, hogy az OECD keretein belül minél hamarabb megszülethessen egy multilaterális megoldás.

Vajon ezek a kritikák megalapozottak? Nos, e tekintetben számos érv létezik pro és kontra. A fejezet zárásaként ezek közül fogunk néhányat áttekinteni.

A digitális adók bevezetése melletti érvrendszer arra hivatkozik, hogy a fizikai jelenléten alapuló társasági adójogszabályok napjainkra elavulttá váltak, s ennek hiányosságait a nagy multinacionális cégek - különböző adóelkerülési stratégiák alkalmazásával - kihasználják. E tekintetben elegendő arra hivatkozni, hogy ezáltal az országok fokozatosan kiszolgáltatottá váltak, s egy lefelé tartó adóverseny alakult ki (lásd korábban). A digitális adók bevezetésével viszont az államháztartás bevételei stabillá válnának, valamint javulna az adóbevételek átláthatósága, ellenőrizhetősége. ${ }^{53}$ Ráadásul, ahogy korábban láthattuk, a digitális cégek adóterhelése jóval alacsonyabb, mint a hagyományos vállalkozásoké, vagyis ez a lépés csak az arányos közteherviselés érvényesülését biztosítaná.

A fenti érvrendszerrel szemben leggyakrabban azt hozzák fel, hogy amennyiben az egyes tagállamok egyoldalúan vezetnek be ilyen típusú adókat, az az egész uniós belső piac integritását fenyegetheti, mivel ezáltal a több tagállamban is tevékenységet folytató vállalkozásokra eltérő szabályok lesznek irányadók, ami csak erősíti a káros adóversenyt. Ez az érv

\footnotetext{
53 Teski-Weltherné-Melcher, 2020. 19.o.
} 
tulajdonképpen nem vonja kétségbe a digitális adók alkalmazását, csak azt szorgalmazza, hogy egységes nemzetközi/uniós megoldásra van szükség az egyéni megoldások helyett.

Ezen túlmenően azonban olyan kritikák is elhangzottak, amelyek alapjaiban támadják ezt az elképzelést, rámutatva annak téves kiindulópontjaira, valamint a káros gazdasági következményeire.

Ezek közül kiemelkedik az az érv, amelyik a közkeletű vélekedéssel szemben azt állítja, hogy ha az effektív társasági adókulcsokat nézzük, akkor a digitális cégek adóterhelése magasabb, mint a hagyományos vállalatoké. Ennek alátámasztására arra hivatkozik, hogy ha a 2012-2017-es időszakot vesszük figyelembe, akkor az olyan nagy digitális cégeket, mint a Google-t, Facebook-ot vagy az Amazont 26,8\%-os adóterhelés sújtotta, míg ez az érték a Spanyolországban és Németországban székhellyel rendelkező hagyományos cégek esetében csak 23,4\%-os volt. Ráadásul az adóelkerülési stratégiák alkalmazása nem korlátozódik a digitális cégekre, azzal jócskán élnek a hagyományos vállalatok is. ${ }^{54}$

További érv, hogy a tagállamok által bevezetni tervezett digitális adók árbevétel alapúak, amelyek komoly gazdasági károkat okozhatnak. E tekintetben elismerik, hogy a társasági adó nem a legalkalmasabb eszköz a kormányzati bevételek növelésére, valamint, hogy azt viszonylag könnyü kijátszani és így adóelkerülést folytatni. Ezenkívül a vállalatok által fizetett adó kevésbé „látható”, mint a magánszemélyek esetében és általános a vélekedés a tekintetben, hogy ha a vállalatok több adót fizetnek, akkor másoknak az adóterhei csökkeni fognak. Azonban ezzel szemben az az igazság, hogy az adókat végső soron nem a vállalatok, hanem az emberek fizetik meg, így a magasabb társasági adókat is. Habár a bevételalapú adó esetében nehezebb az adóelkerülés és a vállalatokat erőteljesebben kényszeríti arra, hogy az adót abban az országban fizessék meg, ahol ténylegesen múködnek, ennek ellenére legalább négy indok szól ellene:

- a gazdasági tevékenységre közvetlenül irányuló adó, ezáltal a holtteher-veszteség is magasabb;

- jobban ráterhelhetik a fogyasztókra, különösen, ha az érintett cégek veszteségesen múködnek;

- rombolják az üzleti környezetet;

54 BAUER, 2019. 4-5.o. 
- a profithoz viszonyítva nagyon magas tényleges adóterhelést eredményezhet. ${ }^{55}$

Ehhez szorosan kapcsolódik az az érv is, hogy - uniós tagállamok esetén - az állami támogatásokra vonatkozó szabályok is sérülhetnek. ${ }^{56} \mathrm{Ha}$ az Európai Bizottság elmúlt években lefolytatott vizsgálatait vesszük alapul, akkor megáll ez a feltételezés. Azonban időközben több ügy is eljutott az uniós bíróságokra - ahogy ezt korábban láthattuk - ahol többek között arra hivatkozva, hogy az adó hatálya alá tartozó, illetve nem tartozó vállalatok nincsenek hasonló ténybeli és jogi helyzetben, felülbírálták ezeket a bizottsági határozatokat, gondoljunk például csak a lengyel kiskereskedelmi adó ügyére. Vagyis a bevételalapú adók nem szükségszerủen eredményeznek tiltott állami támogatást. Ráadásul idén márciusban úgy túnik, hogy az Európai Unió Bírósága lényegében véve eldöntötte ezt a kérdést: a magyar vonatkozású Vodafone és Tesco ügyekben kizárta a tiltott állami támogatás létét, sőt előbbiben azt is megállapította, hogy a letelepedés szabadsága sem sérült. ${ }^{57}$

Végezetül gyakorta elhangzó érv, hogy a digitális adó - akár uniós, akár tagállami változatokról beszélünk - nem más mint egy bújtatott protekcionista törekvés az uniós cégek amerikai társaikkal szembeni versenyhátránya ledolgozásához. Ezt pedig mi sem mutatja jobban, mint hogy valamennyi tervezet esetében a vonatkozó küszöbértékeket olyan magasan határozták meg, hogy azok szinte csak amerikai cégeket érintsenek. ${ }^{58}$ Ennek viszont egyenesen következménye, hogy az USA minden ilyen jellegű uniós vagy egyoldalú lépést gyakorlatilag a cégeit ért támadásnak vesz, ami ellen büntetőintézkedéseket helyez kilátásba, mint a francia GAFA-adó esetében történt.

A fentiek alapján jól látszik, hogy több érv is szól a digitális adók, elsődlegesen a bizottsági tervezetek mellett. Azonban nem lehet figyelmen kívül hagyni azt a tényt sem, hogy számos, döntően gazdasági és politikai érv áll ugyanakkor ezzel szemben. Ennek értelmében pedig érdemes lenne újra gondolni az elképzelést, többek között bevételalapú helyett nyereségalapú adót kellene bevezetni (akár magasabb kulcsokkal is), valamint elsősorban az OECD keretében kellene törekedni egy átfogó

\footnotetext{
55 Jessop-Trovato-MARQUES-SANTACRUZ, 2019. 13-14.o.

56 BORDÁCS, 2019. 4-13.o.

${ }^{57}$ NiCOLAIDES, 2020.

${ }^{58}$ Ennek kapcsán lásd például: HuFBAUER-Lu, 2018. 6.o.
} 
megállapodás elérésére. Ez utóbbi révén ugyanis jelentősen csökkenteni lehetne az amerikai válaszlépések lehetőségét.

\section{KONKLÚZIÓ}

Összességében véve leszögezhetjük, hogy a digitális cégek megadóztatása új kihívást jelent a világ valamennyi országára nézve, mivel ezek a cégek a szolgáltatásaikat konkrét fizikai jelenlét nélkül nyújthatják az adott országban. Ezt pedig a jelenlegi adórendszerek nem tudják kezelni, ugyanis az elmúlt évtizedekben fokozatosan elavulttá váltak, melyet a digitalizáció folyamata csak tovább súlyosbított. Ráadásul ezen túlmenően számolni kell még az adóelkerülési stratégiákkal is, amelyek dollármilliárdokkal kurtítják meg a költségvetéseket.

Mindezek fényében nem véletlen, hogy az elmúlt néhány évben felerősödtek nemzetközi és uniós szinten azok a törekvések, amelyek átfogó társasági adóreformot kívánnak végrehajtani. E tekintetben az OECD és az Európai Unió élen jár: utóbbi 2018 márciusában két javaslatot is letett az asztalra. Néhány tagállam viszont nem támogatta ezeket az elképzeléseket és mivel az adópolitika területén egyhangúság kell, nem született konkrét jogszabályok belőlük. Azonban ez közel sem jelentette azt, hogy a digitális adó lekerült volna a napirendről: a tagállamok folyamatosan hangsúlyozzák, hogy leginkább nemzetközi szinten (OECD) szükség volna egy átfogó megoldásra. Az ezzel kapcsolatos tárgyalások jelenleg is tartanak, de eközben - éppen a bizottsági javaslatok által inspirálva - egyes tagállamok saját digitális adó javaslatokat dolgoztak ki.

Ennek kapcsán a sajtóban a legnagyobb vihart kétségtelenül a francia kezdeményezés okozta, kis híján kereskedelmi háborút is kirobbantva. Ezzel szemben más tervezetek lényegesen kevesebb figyelmet kaptak. Ezek közül kiemelkedik a cseh digitális adó, mely az egyik legmagasabb adóterhet jelentené ezen cégek számára: a kulcs több kétszerese az alapul szolgáló bizottsági javaslatnak. Tekintettel arra, hogy a francia tervezethez hasonlóan ez is magas küszöböket határozott meg, várható volt ebben az ügyben is az USA fellépése. Ez végül nem is maradt el: a konkrét válaszintézkedések belengetésén kívül számos jogi és gazdasági érvet felhoztak a tervezett adó ellen, melyek közül több a bizottsági javaslatokra is vonatkoztatható volt. Vajon indokoltak voltak ezek a kritikák?

Nos, ahogy láttuk, részben igen. Elsősorban azért, mert az unilaterális intézkedések azon túl, hogy veszélyeztetik a belső piacot, amerikai 
válaszintézkedéseket is kiválthatnak. Ez utóbbi kapcsán a vád a cseh valamint más, beleértve a bizottságiakat is! - tervezet ellen az volt, hogy az szinte kizárólag amerikai cégeket céloz. Habár ez tényleg igaz, ez annak köszönhető, hogy ezek a cégek a legnagyobbak és a legbefolyásosabbak a világon (például Google, Apple, Amazon), s ők tudnak a leglátványosabban élni az adóelkerülési stratégiákkal. E tekintetben elegendő csak arra hivatkozni, hogy az Európai Bizottság már évek óta vizsgálja ezen vállalatok stratégiáit és több esetben is tiltott állami támogatást állapított meg pl: Apple - 13 milliárd euró visszafizetését rendelte el (lásd a Jogi háttér c. fejezetben).

Éppen ezért bölcsen járt el Csehország, amikor végül - az amerikai nyomásra hivatkozva - bejelentette, hogy 7\%-ról 5\%-ra csökkenti az adó mértékét és a jövő évre halasztja annak bevezetését. ${ }^{59}$ Ezzel ugyanis elkerülte az esetleges amerikai válaszlépéseket, valamint esélyt adott arra, hogy mire ténylegesen bevezetésre kerülne a jogszabály, addigra már megszületik a nemzetközi megoldás is. Ugyanakkor ez nem jelenti azt, hogy Csehországnak teljesen le kellene mondania a tervezet egyes rendelkezéseiről: képviselheti azokat az OECD keretein belül folyó előkészítő munkálatokban is. Ugyanis a tervezetnek több olyan eleme is van, amelyeket valamilyen formában érdemes lenne megőrizni. Ennek kapcsán érdemes például kiemelni Leonid Bershidskyt, aki véleménycikkében dicséri a cseh digitális adót, mivel az - szemben más tervezetekkel - a felhasználói adatok hirdetési célokra történő felhasználásának tevékenységére helyezi az adóztatás kérdésének a súlypontját. Ezáltal ugyanis a célzott hirdetés válna megadóztathatóvá, végre a társadalom „visszakapna” valamit abból, hogy felhasználják a személyes adatait, továbbá a transzparencia is növekedne (a cégeknek nyilvánosságra kellene hozniuk, hogy mely weboldalakon került sor ezekre a hirdetésekre). ${ }^{60}$

Habár eddig az USA meg tudta akadályozni, hogy a - bizottsági tervezetek bukása után - egyes tagállamok digitális adókat vezessenek be, ez nem feltétlenül jelenti azt, hogy ezzel el is hárította a ,veszélyt”. Ugyanis az önálló tagállami javaslatok eddigi története valójában arra mutat rá, hogy ezek a lépések együttesen a nemzetközi fellépés szükségességét növelik, tehát egyfajta nyomásgyakorló eszköznek tekinthetők. Nem véletlen, hogy a francia pénzügyminiszter nemrég aggodalmát fejezte ki, hogy ha 2020 végéig nem születik átfogó megoldás, akkor sok-sok digitális adó lesz. ${ }^{61}$

\footnotetext{
${ }^{59}$ LAZAROVÁ, 2020.

${ }^{60}$ BERSHIDSKY, 2019.

${ }^{61}$ Portfolio, 2020b.
} 
A fentiek fényében tehát azt mondhatjuk, hogy a digitális cégek megadóztatása biztosra vehetô, egyedül ennek pontos időpontja és módja kérdéses még jelenleg.

\section{FELHASZNÁLT IRODALOM}

Action Plan on base Erosion and Profit shifting (2013), OECD, 1 44 Elérhető: https://www.oecd.org/ctp/BEPSActionPlan.pdf (Letöltve: 2020.02.22.)

AmCham CZ Position on Government Digital Tax Proposal (2019), The Council on Czech Competitiveness Elérhető: http://www.czechcompete.cz/economic-policy/technology-r-and-dand-innovation/amcham-cz-position-on-government-digital-taxproposal (Letöltve: 2020.03.01.)

ANTI TAX Avoidance PACKage (2016). Elérhető:

https://ec.europa.eu/taxation customs/business/company-tax/anti-taxavoidance-package en (Letöltve: 2020.02.24.)

Asen, Elke (2019): Announced, Proposed, and Implemented Digital Services Taxes in Europe, Tax Foundation. Elérhető: https://taxfoundation.org/digital-taxes-europe-2019/ (Letöltve: 2020.02.28.)

AZ EuRÓPAi PARLAMENT 2019. MÁRCIUS 26-I ÁLlÁSFOGLALÁSA A PÉNZÜGYI BÜNCSELEKMÉNYEKRŐL, AZ ADÓKIJÁTSZÁSRÓL ÉS AZ ADÓKIKERÜLÉSRŐL (2018/2121(INI))

BAUER, MATTHIAS (2019): Digital service taxes as barriers to trade, ECIPE, 1-7 Elérhető:

https://ecipe.org/wp-

content/uploads/2019/11/CaseStudy DigitalService.pdf (Letöltve: 2020.03.01.)

Bershidsky, LEONID (2019): This Is the Best Way to Tax Google and Facebook, Bloomberg. Elérhetô: https://www.bloomberg.com/opinion/articles/2019-05-03/the-czechrepublic-s-new-digital-tax-is-the-right-approach (Letöltve: 2020.03.02.)

BORDÁCS BÁLINT (2019): A digitális szolgáltatási adó állami támogatás jellegének kérdése, Versenytükör, Gazdasági Versenyhivatal, XV. évf., 2019/2. szám. 4-13. Elérhetô:

https://www.gvh.hu/pfile/file?path=/gvh/kiadvanyok/versenytukor/la pszamok/versenytukor 2019 02\&inline=true (Letöltve: 2020.02.28.) 
Commission StafF Working DOCUMEnt, ImPaCt Assessment, SWD (2018) 81 final,

Czech Republic: Digital services tax, update (2019), KPMG. Elérhető: $\quad$ https://home.kpmg/us/en/home/insights/2019/11/tnfczech-republic-digital-services-tax-update.html (Letöltve: 2020.02.29.)

DONALD IS ALREADY PUNISHING THE CZECH REPUBLIC, AND WE HAVE NOT YET INTRODUCED THE 'GOOGLE' TAX (2020), Engnews24h. Elérhető: http://engnews24h.com/donald-is-already-punishing-theczech-republic-and-we-have-not-yet-introduced-the-google-tax/ (Letöltve: 2020.03.01.)

DrAFt BILl ON TAXATION OF DigitAl SERVICES (2019), Fucik. Elérhető: http://www.fucik.cz/en/articles/draft-bill-on-taxation-of-digitalservices/ (Letöltve: 2020.02.28.)

ERDőS ÉVA (2019): A digitális gazdaság és kereskedelem árnyoldala: a digitális adóelkerülés nemzetközi tendenciái, Miskolci Jogi Szemle, 14. évfolyam (2019). 2. különszám. 1. kötet 235-245. Elérhető: https://www.mjsz.uni-miskolc.hu/files/6555/25 erdoseva tördelt.pdf (Letöltve: 2020.02.20.)

EURÓPA A GOOGLE ÉS A FACEBOOK MEGREGULÁZÁSÁT TEKINTENÉ AZ IDEI LEgFontosabB FeladatnaK (2020), Portfolio. Elérhető: https://www.portfolio.hu/uzlet/20200214/europa-a-google-es-afacebook-megregulazasat-tekintene-az-idei-legfontosabb-feladatnak415991 (Letöltve: 2020.02.27.)

FAIR TAXATION OF THE Digital ECONOMY (2018). Elérhető: https://ec.europa.eu/taxation customs/business/company-tax/fairtaxation-digital-economy en (Letöltve: 2020.02.26.)

Hufbauer, Gary Clyde-Lu, Zhiyao (LuCy) (2018): The European Union's Proposed Digital Services Tax: A De Facto Tariff, Peterson Institute for International Economics, 1-11 Elérhető: https://www.piie.com/system/files/documents/pb18-15.pdf (Letöltve:2020.03.02.)

Jessop, Julian-Trovato, Massimiliano-Marques, NicolasSANTACRUZ, JAVIER (2019): The case against tech taxes, Epicenter, 1-38 Elérhető: $\quad$ http://www.epicenternetwork.eu/wpcontent/uploads/2019/06/The-case-against-Tech-Taxes web.pdf (Letöltve: 2020.03.02.) 
KÁoszra FigyelmezteT a FrAnCia PÉNZÜGYMiniszTer (2020), Portfolio. Elérhető: $\quad$ https://www.portfolio.hu/uzlet/20200224/kaoszrafigyelmeztet-a-francia-penzugyminiszter-416875 (Letöltve: 2020.02.27.)

KISS BALÁzS (2020): Prága nem tart az amerikai retorziótól, Infostart. Elérhetô: $\quad$ https://infostart.hu/tudositoink/2020/01/25/praga-nemtart-az-amerikai-retorziotol (Letöltve: 2020.02.29.)

LAZAROVÁ, DANIELA (2020): Czech finance minister ready to postpone, cut proposed digital tax, Radio Prague Interrnational. Elérhető: https://www.radio.cz/en/section/business/czech-finance-ministerready-to-postpone-cut-proposed-digital-tax (Letöltve: 2020.03.02.)

N. Michel, ADAM (2019): The Treasury Should Disengage from the OECD Digital Tax Process, Backgrounder, No. 3445. 1-8. Elérhető: https://www.heritage.org/sites/default/files/2019-10/BG3445.pdf (Letöltve: 2020.02.27.)

Nicolaides, Phedon (2019): The Problem with Turnover Taxes, State Aid Hub. Elérhető:

http://www.stateaidhub.eu/blogs/stateaiduncovered/post/9543 (Letöltve: 2020.02.29.)

Nicolaides, Phedon (2020): Has an Economic Myth Become a Legal Fact? The Case of Turnover Taxes, State Aid Hub. Elérhető: http://stateaidhub.eu/blogs/stateaiduncovered/post/9623 (Letöltve: 2020.03.02.)

PROPOSAL FOR A COUNCIL DIRECTIVE LAYING DOWN RULES RELATING TO THE CORPORATE TAXATION OF A SIGNIFICANT DIGITAL PRESENCE, COM (2018) 147 final

Proposal FOr a COUNCIL DiRECTIVE ON A COMMON CORPORATE TAX BASE, EUROPEAN COMMISSION, COM (2016) 685 final

PROPOSAL FOR A COUNCIL DIRECTIVE ON THE COMMON SYSTEM OF A DIGITAL SERVICES TAX ON REVENUES RESULTING FROM THE PROVISION OF CERTAIN DIGITAL SERVICES, COM (2018) 148 final

RÁCZ DÁNIEL (2014): A nemzetközi adózás új kihívásai: a digitális gazdaság, Jogi tanulmányok, 17. évf., 2014/1. szám, 312-322. Elérhető: http://epa.oszk.hu/02600/02687/00006/pdf/EPA02687_jogi_tanulma nyok_2014_312-322.pdf (Letöltve: 2020.02.25.)

RAWLINGS, GREGORY (2017): Shifting profits and hidden accounts: Regulating tax havens. In: DRAHOS, Peter ed.: Regulatory Theory: Foundations and applications., Canberra ANU Press. 653-674. Elérhető: 
http://press-files.anu.edu.au/downloads/press/n2304/pdf/ch37.pdf (Letöltve: 2020.02.20)

SAUDI ARABIA G20 2020, G20.org. Elérhető:

https://g20.org/en/LeadersSummit/Pages/RiyadhSummit.aspx

(Letöltve: 2020.04.20)

STAVICZKY PÉTER (2018): Az uniós joggal összeegyeztethetők a sávos különadók, SZAKma, 2018/10. szám. 22-23

SZƯCS GÁBORNÉ (2020): Az online kereskedelem térhódítása és szabályozása, Külügyi Műhely, 2020/1. szám DOI azonosító: https://doi.org/10.36817/km.2020.1.4

T-836/16. és T-624/17. sz. Lengyelország vs. Európai Bizottság egyesített ügyek, [ECLI:EU:T:2019:338].

TAX GAMES: THE RACE TO THE BOTTOM, EUROPE'S ROLE IN SUPPORTING AN UNJUST GLOBAL TAX SYSTEM (2017), Eurodad, 1-176 Elérhető: https://eurodad.org/files/pdf/1546849-tax-games-the-race-to-thebottom.pdf (Letöltve: 2020.02.25.)

TAX RULINGS (2013). Elérhető:

https://ec.europa.eu/competition/state aid/tax rulings/index en.html (Letöltve: 2020.02.24.)

TESKI NORBERT-WelTherné SZOLNOKI DÓRA-MelCher ISTVÁn (2020): A digitális gazdaság megadóztatásának aktuális kérdéseirôl, a modern gazdasághoz illeszkedô új uniós adószabályokról értékelő elemzés figyelemmel a terület ellenőrizhetőségére, Állami Számvevőszék, 1-25 Elérhetô:

https://asz.hu/storage/files/files/elemzesek/2020/a digitalis gazdasag megadoztatasa 20200313.pdf?download=true (Letöltve: 2020.02.28.)

TRUMP HARAgJa CSAPHAT LE CSEHORSZÁGRA - AlAKul EgY ÚJ KERESKEDELMI FESZÜLTSÉG (2020), Portfolio. Elérhető: https://www.portfolio.hu/gazdasag/20200124/trump-haragja-csaphatle-csehorszagra-alakul-egy-uj-kereskedelmi-feszultseg-413589 (Letöltve: 2020.03.01.)

Új Globális vállalati adóra tetTek javaslatot (2019), Portfolio. Elérhető: https://www.portfolio.hu/gazdasag/20191108/uj-globalisvallalati-adora-tettek-javaslatot-406579 (Letöltve: 2020.02.22.)

VALERO, JORGE (2020): Europeans to pass digital tax by end 2020 if no OECD deal, Euractiv. Elérhető: 
https://www.euractiv.com/section/economy-jobs/news/europeans-topass-national-digital-tax-by-end-2020-if-no-oecd-deal/ (Letöltve: 2020.02.27.)

VARGA ERZSÉBET (2019): A nemzetközi adójog kihívásai a globalizáció és a digitális gazdaság tükrében, Iustum Aequum Salutare, XV. évfolyam. 2019/3. szám. 107-109. Elérhető:

http://ias.jak.ppke.hu/hir/ias/20193sz/10 VargaE \%20IAS 2019 3.p df (Letöltve: 2020.02.25.)

VARGHA BÁLINT (2017): Adóalap-elvonási tünetek? Áttekintés az offshore tőke kiáramlásáról, Pénzügyi Szemle, 2017/2. 190-213. https://www.penzugyiszemle.hu/documents/vargab-2017-2mpdf 20170717143233 23.pdf (Letöltve: 2020.02.20)

WÁGNER TAMÁs (2017): Adójellegú állami támogatások - A magyar reklámadó és az uniós jog. In: Bragyova András szerk.: Miskolci Doktorandusz Konferencia Tanulmánykötet, Miskolc, Bíbor Kiadó. 286300

WÁGNER TAMÁS ZOLTÁN (2019): Kiskapu az állami támogatásokra vonatkozó uniós szabályozásban, különös tekintettel a McDonald's ügyre, Iustum Aequum Salutare, XV. évfolyam. 2019/4. szám. 181-203. Elérhetô:

http://ias.jak.ppke.hu/hir/ias/20194sz/11_WagnerTZ_IAS_2019_4.pdf (Letöltve: 2020.02.22.)

WÁGNER,TAMÁS ZOLTÁN (2020): Role of tax havens in tax avoidance by multinationals with special regard to Ireland in Hoghová, KristínaKlimovský, Daniel-Kolman, Boris eds.: Sociálne Vedy z Perspektívy Mladých Vedeckých Pracovníkov IV. Trnava 2020, Fakulta sociálnych vied Univerzita sv. Cyrila a Metoda v Trnave. 333-341. Elérhető: http://fsvucm.sk/files/konferencie/mladi\%20sociálni\%20pracovníci/20 20/Wagner.pdf (Letöltve: 2020.02.27) 